\title{
ISLAMIC KNOWLEDGE AND ATTITUDES TOWARD HIV/AIDS AMONG UNDERGRADUATES IN UPM SERDANG
}

\author{
${ }^{1}$ Hanina HalimatusaadiahHamsan \\ ${ }^{2}$ Lee Mei Siah \\ ${ }^{1,2}$ Department Of Social And Development ScienceFaculty \\ Of Human Ecology Universiti Putra Malaysia \\ hanina@upm.edu.my
}

\begin{abstract}
Research has been conducted attitudes related HIV/AIDS issue particularly among university students because students are the group of younger generation that may be parents advising their children in future or they may have to contact with HIV infected and AIDS people in their future work. The purpose of research design is to identify the most economical method in conducting the research. The nonexperimental quantitative research design which is in questionnaire tools has used to finalize results that are based on hypothesis testingThe population of this study is targeted to the undergraduates from Human Ecology in UPM, Serdang. The sample size for the study is determined by the calculation formula (Israel, 2009). The minimum sample size for FEM is approximately 271 , which is calculated by the formula of known population size $(\mathrm{N}=835)$ with the $95 \%$ confidence level and confidence interval of $5 \%$.to achieve the objectives for this current study. Besides, three techniques of research design are descriptive, correlation and comparative also have been chosen in this study. Descriptive design is used to gather the quantitative information and then organizes, tabulates, depicts, and describes the data collection. Descriptive involved in this study will be given a general description about respondent's personal characteristic (gender), level of knowledge in HIV/AIDS and attitudes toward HIV/AIDS. The correlation design is applied to determine the linear relationship between personal characteristic (gender), knowledge and attitudes towards HIV/AIDS among FEM undergraduates. The result of the correlation can be positive and negative. If the result is positive correlation, then the changes in value of one variable will make the changes of the other variables in the same direction, or vice versa.
\end{abstract}

Keyword : Knowledge, attitudes, HIV, Islamic

\section{Background of the Study}

$\mathrm{HIV}$ is defined as the virus that causes the disease AIDS. It has become one of the most serious health and development challenges in both developed and developing countries around the world (www.aids.gov, 2011). HIV infection and AIDS can affect physical, mental, emotional, social and spiritual dimensions of 
human development life. Besides, HIV/AIDS is not merely a health problem but also impact on social, economical, security and development. It is significant reducing the life expectancy of those infected persons, increasing in the number of orphaned children, creating turbulence in health care systems, and contributing to economic insecurity, potentially leading to political instability (Sowell, 2004).HIV infection pandemic posses a great threat to human life and cause significant morbidity and mortality throughout the world population (WHO, 2004).

According to the United Nations Agency for International Development (UNAIDS, 2011), about 34 million people worldwideas December 2010 were living with HIV, the virus that causes AIDS. UNAIDS alsoreported that every year around 2.7 million more people become infected with HIV and 1.8 million die of AIDS. In Malaysia, the first three HIV case were reported in 1986. Between of 1986 to 2000 , it was recorded about 38,340 cases. Then, the total number of HIV infection cases continued to grow with the highest number recorded in the end of 2011 at 94,841 (www.moh.gov.my, 2012).The HIV infection in Malaysia affected more men than women initially but the percentage of women infected by HIV keeps increasing year by year. Every day, an average of 10 people tested with positive HIV in Malaysia (Ministry of Health Malaysia, 2012). According to Ministry of Health of Malaysia, young populations are at higher risk exposed to HIV infection. Of the total $94,841 \mathrm{HIV}$ infection cases, $2.4 \%$ cases were aged 19 years and below.In 2011, children and young people for aged 19 years and below were $3.5 \%$ of 3,479 for that year out of which $54 \%$ aged below 13 years who acquired infection through vertical transmission.
The HIV/AIDS diseases significantly slow the growth of the labour force and also affect the most productive members especially younger generation in several sectors since previous study found that young people are particularly vulnerable to sexually transmitted HIV/AIDS infection (Suominen,Karanja-Pernu, Kylma,Houtsonen\&Va"lima"ki,2011).

Therefore, this phenomenon has makes governmentand public worried about the unhealthy attitudes of nowadays younger people of the society especially students are engage in risky behaviour related to HIV/AIDS transmission such as use of alcohol, intravenous drugs, unprotected homosexual or heterosexual intercourse and free sex that could increase their risk of HIV infection and AIDS diseases due to the lack of general knowledge on HIV/AIDS exposure and transmission.

The epidemic of HIV/AIDS stigma has consequences and can result in attitudes and actions that may prevent infected people from seeking or obtaining the health care and social support. HIV/AIDS is labeled as a stigmatized disease from the past research of stigma in HIV positive women, indicated that women infected with HIV/AIDS faced the consequences of stigmatization in their life such as being stigmatized and rejected by their partners, relatives, friends, employers, co-workers and also health care providers (Sandelowski, Lambe\&Barroso,2004). Besides, a past study also mentioned that healthcare workers expressed their fear to care for HIV/AIDS patients (Turan, Miller, Bukusi, Sande\& Cohen, 2008).People's negative attitude toward people living with HIV/AIDS (PLWHA) is a major community challenge to fight against HIV/AIDS. People who may be infected with HIV/AIDS are more reluctant to disclose their status due to feeling 
stigmatized, rejected and isolated (Colbert, Kim, Sereika\&Erlen, 2010; Naing, Hakim, Ang, Koo, Tan, Kong \&Siew, 2010) and potentially less engaged in care (Colbert et al., 2010).

Studies also stated that poor knowledge about HIV/AIDS can make people to have negative attitudes towards HIV/AIDS and this will directly contribute to theglobal problem of stigmatization against PLWHA. According to Ojebuyi (2009), the factors probably that cause the stigma and discrimination attitudes against people with HIV/AIDS are the public's inadequate knowledge and strong misconceptions about the pandemic.Knowledge on HIV/AIDS means facts, information, and understanding about the HIV/AIDS. Knowledge influenced by cultural factors and gained especially through learning and experience. Level of knowledge on HIV/AIDS frequently related with theattitudes toward PLWHA, and those with less HIV/AIDS knowledge are often thosepossess negative stigma attitudes. Result of previous research study proved that attitude was significantly positive correlated with knowledge (Montazeri, 2005; Meundi, Amma, Rao\&Shetty, 2008). A study about HIV knowledge, attitudes and misconceptions was conducted in Turkey reported that respondents who were well educated and living in the city showed more positive attitudes toward people living with HIV/AIDS (Ayranci, 2005).

Study in knowledge, attitude and behaviour of the students from medicine faculty, dentistry faculty, and medical technology vocational training school mentioned that about HIV/AIDS infectious diseases is crucial because it will affect the students of these professions' care toward HIV/AIDS patients in the future (Turhan, Senol, Baykul, Saba \&Yalçin, 2010). Besides, another previous study indicated that exist of fear in HIV/AIDSdue to the poor understanding of the disease in Nigerian population, even among thehealthcare providers are reluctant to treat people infected with HIV/AIDS (Monjok,2009). Thus, the positive attitudes and knowledge on HIV/AIDS should be emphasized and implemented into the students especially those who will become health care providers in the future.

\subsection{Statement of Problem}

Research has been conducted attitudes related HIV/AIDS issue particularly among university students because students are the group of younger generation that may be parents advising their children in future or they may have to contact with HIV infected and AIDS people in their future work (Serlo, 2008). It is prudent to conduct the study among university students to ascertain their knowledge and attitudes regarding HIV/AIDS. Therefore, the present study investigated the relationships between knowledge and attitudes toward HIV/AIDS among undergraduates in UPM (Universiti Putra Malaysia), Serdang.

The purpose of this study is to identify the knowledge HIV/AIDS and attitudes toward HIV/AIDS among undergraduates in UPM, Serdang. Specifically, this study will identify respondent'spersonal characteristic (gender)related to knowledge andattitudes toward HIV/AIDS. In addition, this study determines the relationship between respondent'spersonal characteristic (gender)with HIV/AIDS knowledge and attitudes toward HIV/AIDS. In summary, the following are the researches questions will be addressed in this study:

a) What is the level of knowledge on HIV/AIDS among the respondents? 
b) To what extent is respondent's personal characteristic (gender) related to knowledge of HIV/AIDS and attitudes toward HIV/AIDS?

c) To what extent is knowledge of HIV/AIDS related to respondent's attitudes toward HIV/AIDS?

d) What factors uniquely predict attitudes toward HIV/AIDS of the respondents?

\subsection{Conceptual Framework}

This framework consists of antecedent variable (respondents' personal characteristic), independent variable (HIV/AIDS knowledge) and dependent variable (attitudes toward HIV/AIDS). As studies suggest that attitudes toward HIV/AIDS is greatly influence by people's knowledge (Montazeri, 2005; Meundi et al., 2008), therefore knowledge on HIV/AIDS will be used in the model to access the attitudes of respondents.

Knowledge is the perception of reality acquired through learning and investigation expressed in a form that can be shared.The level of knowledge of students will affect their perception of how HIV/AIDS is acquired and this can contribute on how they express either positive or negative attitude toward HIV/AIDS. Naing, Hakim, Ang, Koo, Tan, Kong \&Siew(2010) stated that to have better perceptions toward HIV/AIDS depends on an improved the knowledge of HIV/AIDS mode transmission.

The study of the knowledge and attitudes toward HIV/AIDS is important to understand how attitudes would be affected by the personal characteristic and knowledge of HIV/AIDS among undergraduates in UPM. This finding may contribute significantly to the development at three various levels. The first is individual level, next at society level and finally at national level. At individual level, findings maybenefits to the students themselves as the study may create or increase awareness of the effects of the HIV/AIDS knowledge on their attitudes toward HIV/AIDS. Perhaps that the students will be more tolerance and understandings of those that have been affected by HIV/AIDS so that the HIV/AIDS stigmatization and discrimination issues can be reduce to the minimum.

At society level, essential information may gain from the findings and thus provide a better understanding toward HIV/AIDS on younger people and education. Parents, teachers and many more related social institutions could be benefited from the findings in order to provide better guides according the ways to promote more positive understanding toward HIV/AIDS among their younger generation. For example, policy makers in the educational institutions may benefit from this result in planning for general knowledge of HIV/AIDS related courses to be taught in throughout curriculum.At national level, the findings from this study may provide useful information that can be referred by the government, non-government agencies and also education centre as guidance to organize appropriate plan or program on HIV/AIDS to educate public or students. This appropriate program can enhance the knowledge and attitudes toward HIV/AIDS and this also will indirectly to reduce the prevalence of HIV/AIDS stigmatization and discrimination issues that happen in our society.

\subsection{Definition of Terminology}

Personal Characteristic, Conceptual: The personal characteristic include gender; motivation; sexual orientation; values, attitudes, and beliefs; education; 
personality; focus on relationship function; leadership style; and political beliefs (O'Connell \& Cuthbertson, 2009). Personal characteristics are unique to a particular person. Operational: Personal characteristic in this studyrefer to the gender of the respondent. Gender is indicated by male and female.

HIV/AIDS Knowledge Conceptual: Knowledge represents reality in thought or experience the way it really is on the basis of adequate grounds (Moreland, 2009).Knowledge ofHIV/AIDS means facts, information, and understanding about the HIV/AIDS.Operational:Respondent's score on HIV/AIDS knowledge Scale for Hispanics wasproposed by Luquis and Koch (1991). High score indicates higher level in the knowledge of HIV/AIDS.

HIV/AIDS Attitudes Conceptual: Attitudes often correlated with behavior and can be defined as positive or negative feelings toward a fact (Population Council, 2011). Attitudes generally can be defined as positive or negative views about HIV/AIDS. Operational: Report on scores obtained by respondent in HIV/AIDS Attitudes Scale for Hispanics was proposed by Luquis and Koch (1991). Respondent who get higher score indicates positive attitudes toward HIV/AIDS.

Undergraduate Conceptual: A university or college student who is studying for their bachelor's degree (Piero, 2010). Operational: UPM's undergraduate student.

\section{Knowledge on HIV/AIDS}

Knowledge is a cognitive component of attitude that describes whatpeople think and perceived. The students' general knowledge about HIV/AIDS was associated with the program of study or facultythey attend such as the earlier study indicatedthat students from Faculty of Health Sciences were more knowledgeable about HIV/AIDS compared to Faculty of Arts and other selected faculties of the university (Aluede, Imhonde, Maliki\&Alutu, 2005).In an addition, the study in New Delhi high school reported that knowledge of HIV/AIDS was significantly correlated with the exposure of HIV/AIDS education (Pramanik, Koopman\&Chartier, 2006), which means the greater exposure to the HIV/AIDS education showed that higher knowledge of HIV/AIDS.

The study by Pramanik and colleagues (2006) also revealed that majorityof students agreed that schools and universities should teach HIV/AIDS and sex education, and also believed that it was a society' duty to educated people about the HIV/AIDS.Similary, a study stated that majority of Arab University students agreed that young people need to know more information and should be given education on how to protect themselves against HIV/AIDS and about half of them expressed that they had not been taught enough at school (Ganczak, Barss, Alfaresi, Almazrouei, Muraddad\& Al-Maskari, 2007). Another study about knowledge and attitude towards HIV/AIDS among Iranian students, also mentioned that majority of students said that wish to know more information about HIV/AIDS and most of students agreed with the response in the question of investment on youth education, which is the best way to fight AIDS diseases (Tavoosi, Zaferani,Enzevaei,Tajik\&Ahmadinezha d, 2004). Thus, HIV/AIDS must be addressed by education that recognized the attitudes toward HIV/AIDS, which can increase the awareness among young people on how to protect themselves from the risk of HIV/AIDS infection (Ganczak et 
al., 2007; Pramanik, Koopman \& Chartier, 2006).

Additionally, the level of knowledge was significant associated with attitudes (Montazeri, 2005; Meundi et al., 2008;Rahnama,Rampal, Lye\&Rahman, 2011; Suominen et al., 2011), those who possess stigma attitudes are often those with lower levels of HIV/AIDS knowledge or viceversa. Some previous studies indicated that misconception sorinadequate of knowledge about how HIV is transmitted have significantly correlated with stigmatizing and negative attitudes towards PLWHA (Ganczak et al., 2007;Sallar, 2009; Zhang, Li, Mao, Stanton, Zhao, Wang \&Mathur, 2008). In addition, people with better understanding of HIV/AIDS knowledge tended to view PLWHA in a more positive perception than those without the knowledge (Varas-Díaz, SerranoGarcía\& Toro-Alfonso, 2005). Similarly, several research studies also found that students with high levels of knowledge about HIV/AIDS showed more positive attitudes toward HIV/AIDS (Montazeri, 2005; Meundi et al., 2008;Suominen et al., 2011).

Furthermore, the study on knowledge, attitudes, and educational needs among Arab University students in United Arab Emirates was carried out by Ganczakand colleagues (2007), they reported that most students had a good knowledge on main route of HIV transmission mode such as HIV can be infected through mother to fetus and having unprotected sexual intercourse with an HIV-infected person, but misconception was still existed. Similarly, study also found that tertiary students in Papua New Guineaoverall had high level of knowledge about the transmission and causes of HIV/AIDS (Jose, Totona, Begani, Andew, Tombe \& Begani, 2011). However, many misconceptions about HIV/AIDS such as they perceived that a person can be infected with HIV by eating HIVinfected food, sharing comb and hairbrush, casual kissing, donating blood and mosquito bites. This study result showed that knowledge scores about HIV/AIDS were low becauseonly one student had a high HIV/AIDS knowledge level. Besides, the another study about AIDS knowledge and attitudes among the general public in Tehran, Iran byMontazeri (2005) also showed that there was also exist of misconception about the diseases among Iranian although they had a fairy good in knowledge of HIV/AIDS.

Other studies also showed that studentslack of knowledge or misinformation about virus transmission include drinking water, sharing utensils, shaking hand, sneezing and coughing, using public swimming pools, using public toilets, and mosquito bites (Meundi et al., 2008; Koksal, Namal, Vehid\&Yurtsever, 2005; Pramanik, Koopman\&Chartier, 2006; Tung, Ding\&Farmer,2008). Additionally, previous studies also found that misconceptions about HIV/AIDS transmission still existed, such as the belief HIV/AIDS can be contracted from mosquito bites, saliva or physical touch (Nainget al., 2010); children would never be contracted by HIV/AIDS, HIV-positive people can be recognized by their appearance, and believed that there is a cure and vaccine for AIDS(Tavoosiet al., 2004).

Meanwhile, a study found that students who do not have misconceptions of HIV transmission modes, but still possess stigmatizing attitudes towards PLWHA (Zhang et al., 2008). Moreover, some studies also found that stigma and intolerant attitude toward HIV and AIDS was not associated with the level of HIV/AIDS knowledge among students (Pramanik, Koopman \& Chartier, 2006; Zhang et al., 2008; Serlo, 2008). Study 
by Norman, Carr and Jime'nez (2006) proposed that intolerant attitudes toward PLWHA associated with the disapproval of socially unacceptable behaviors, such as drug use, homosexuality and commercial sex. Therefore, knowledge itself does not always enough to change attitudes alone and more consideration needed to find appropriate and effective ways to educate the general public, students and health care professionals.

\section{Attitudes toward HIV/AIDS}

An attitude toward HIV/AIDS is the perception or how a person views HIV/AIDS disease. The perception of how HIV/AIDS was acquired is crucial on how people will treat a people infected with HIV/AIDS. Attitude often correlated with behavior and can be defined as positive or negative feelings toward a fact (Population Council, 2011). According to Uutela (1985), concept of attitude defined in three components which are involve cognitive such as knowledge that describes what people think, affective such as feeling, and behaviour such as action describes how they would like to behave in a specific way. Moreover, attitudes can be define as a positive, negative, or mixed reaction to a person, object or idea (Brehm, Kassin\& Fein, 2002). It means at times people also can posses both positive and negative evaluation to the same attitude object towards a person or object, and it is not simply represented along a single continuum ranging from wholly positive to wholly negative.

People whose has right knowledge normally has right attitude towards one object. Previous studies have identified that some factors such as level of knowledge on HIV/AIDS (Serlo, 2008; Lau \&Tsui, 2005) andgender (Visser, Makin\&Lehobye, 2006; Serlo, 2008)were closely associated with attitudes towards
HIV/AIDS.Besides, the earlier findings found that students' attitude are affected by the factor of faculty they attend, which mentioned that medical students had more acceptable attitudes towardHIV/AIDS or infections victims than non-medical students (Maimaiti, Shamsuddin, Abdurahim, \&Tohti, 2010; Tan,Pan, Zhou, Wang \&Xie, 2007).Apart from these factors, other studies also found that age (Visser, Makin\&Lehobye, 2006;Zhang et al., 2008), race and ethnicity (VarasDíaz, Serrano-García\& Toro-Alfonso, 2005), culture (Abiona, 2006; Ellepola et al., 2011), religion (Vasan, Sarma\&Thankappan, 2000), and experience of personal interaction with HIV/AIDS infected people (Visser, Makin\&Lehobye, 2006) were significant impact one's attitudes toward victims of and HIV/AIDS.

The unfavorable attitudes toward HIV/AIDS could also be influenced by the prevalent negative attitudes toward people with HIV/AIDS. A previous study by Sallar (2009) in Africa found that people hadnegative attitudes toward and fear of PLWHA, where the adolescents in a Nigerian viewed that PLWHA should be quarantined and they also would reject relatives and also stop seeing friends who develop AIDS. Moreover, the research of knowledge and attitudes toward HIV/AIDS among Turkish students by Koksal and colleagues (2005) found that more than half of the young students expressed that people who infected with HIV should not be allowed to work. Besides, study of knowledge and attitudes toward HIV/AIDS by Tavoosi and colleagues (2004) indicated that negative attitude were common among Iranian students, with they expressed that HIV/AIDS-infected students should not allowed to attend an ordinary schools, they avoid to sit in a class near an infected person, and they would not 
willing to shake hands with a HIV positive person.

Additionally, a studywas conducted in Hong Kong also found that HIV/AIDS infected people are often discriminated and stigmatized against by others (Lau \&Tsui, 2005). Lau and colleagues (2005)indicated that nearly half of the residents would not make any physical contact with PLWHA and one thirdof them agreed medical staff infected with HIV should be dismissed and the other half agreed there should be legislation barring PLWHA from visiting Hong Kong. Similarly, the study was conducted in a semi-urban community, Malaysia reported that household setting was afraid to make physical contact and reluctant to share food and drinks with infected victims (Naing et al., 2010) and this can lead to physical and social ostracization of HIV/AIDS-infected person and discrimination that would reduce supportive networks and increases isolation especially in communities.

Besides, previous study by Chen, Choe, Chen, and Zhang (2007) also indicated that fear of becoming infected with HIV infection can lead to the stigmatization and discrimination of PLWHA. Other studies also revealed that students had a sense of fear and negative intolerant attitudes toward PLWHA(Ganczak et al.,2007;Parker \&Aggleton, 2002; Koksalet al.,2005). Studies also indicated that students had negative feelings due to the fear of infected with the HIV/AIDS virus since there is currently no cure available for HIV/AIDS (Abiona, 2006; Serlo, 2008) and majority of students perceived that AIDS as a serious disease (Ganczak et al., 2007).

On the other hand, research study by Norman and colleagues (2006) found that groups like sex worker, homosexuals and having sex with multiple partners have socially marginalized syndrome as they are being blamed for their disease and they are likely received less sympathy and compassion than others group of HIV/AIDS infected person. It is because students associated HIV/AIDS with immoral sexual behavior such as having sex with prostitutes or promiscuous that is often regarded as shameful and embarrassing. Pramanik and colleagues (2006) alsostated that adolescents perceived the sexual relationship out of marriage and homosexual is wrong; and agreed that people who have HIV/AIDS deserve it and also is a God's punishment for bad behavior.

Furthermore, attitude towards HIV/AIDS will affect the tendency of help and care giving to PLWHA. Some studies showed that students with positive attitudes toward HIV/AIDS were more willing to care for PLWHA when compared to students with negative attitudes. For example, Suominen et al. (2011) and Vasan, SarmaandThankappan(2000) found that students with positive attitudes towardHIV/AIDS disease or PLWHA were willing to take care of them despite neverhave any personal contact with such persons before. However, stigmatization problem was occurred among university students in Malaysia since the finding by researches showed that the majority of the students were not willing to care a person with HIV in their own house (Rahnama, Rampal, Lye \&Rahman, 2011).

Interestingly, another study by Jose et al. (2011) indicated that tertiary students in Papua New Guinea had considerate, compassionate and positive attitudes toward those who are HIV/AIDS-infected people. From the result of this study showed that great majority of the students were afraid of getting the disease, and less than half of them prefer to keep away from those infected with HIV/AIDS 
disease. Most of the students also disagree with the statement that those people with HIV disease should be separated from their normal community life. Such attitudes are considered very positive and healthy attitudes regarding HIV/AIDS toward the HIV/AIDS victims in confronting this HIV/AIDS pandemic.

\section{PersonalCharacteristics (gender) and Gender versus HIV/AIDS Knowledge}

Previous study was conducted among Tertiary Students in Papua New Guinea found that there was a gender difference in knowledge about HIV/AIDS (Jose et al., 2011). Other past research literature studies alsoshowed that females exhibited a significantly higher level of knowledge about modes of transmission of HIV/AIDS than males (Albrektsson, Alm, Tan \&Andersson, 2009; Meundi et al., 2008).However, other findings by the prior researchesrevealed that male had higher knowledge as compared to female (Ganczak et al., 2007; Jose et al., 2011; Pramanik, Koopman \& Chartier, 2006; Vasan, Sarma \& Thankappan, 2000).

Moreover, the study by $\mathrm{Ng}$ and Kamal (2006) also indicated that a gender difference in how adolescent perceived sexual risk of contracting HIV/AIDS and attitudes toward condom use. Furthermore, another study indicated that more males performed better in the two questions of knowledge and practice than females, where transmission of the disease via oral transmission andprevention by using condoms correctly during sexual intercourse (Tan et al., 2007). Besides, the result of the study from Pramanik and colleagues (2006) reported that male had better knowledge because of their greater exposure to the HIV/AIDS education as compare to female.Study on tertiary students in Papua New Guinea by Jose and colleagues (2011) attributed similar findings to the fact that more peer education among males than females due to the reason of the males feel comfortable to talk and learn about HIV/AIDS more than females who may be feel shy or not comfortable when talk about such sensitive issue.

\section{Gender versus Attitudes toward HIV/AIDS}

Previous studies also indicated that the gender difference closely connected with attitudes toward HIV/AIDS (Serlo, 2008; Visser, Makin\&Lehobye, 2006). Research study showed thatmale expressed more acceptance and positive attitudes toward HIV/AIDS-infected people than females (Tan et al., 2007). In contrast, a study indicated that females had more tolerant and better attitudes toward PLWHA compare to malesbecause females showed more compassionate and empathy toward people with HIV/AIDS(Ganczak et al., 2007). Previous studiesalso mentioned that the gender role of females as caregivers in families were more understanding and sympathetic with the diseases (Baron\& Byrne, 2002) and more female than male students felt that they could talk about HIV/AIDS matters to their parents (Albrektsson et al., 2009).

In comparison, other prior research studies proved that there was no significant difference of attitudes toward AIDS between male and female (Ellepola, Joseph, Sundaram\& Sharma, 2011; Meundi et al., 2008; Montazeri, 2005). Although the findings by Montazeri (2005) showed that there was no significant difference in attitudes score across gender, and positive attitudes toward AIDS and people with AIDS infection was found among the general public in Tehran, Iran. Unlike the findings of Montazeri 
(2005), study conducted by Ellepola and colleague (2011) in Kuwait University indicated that majority of students expressed negative attitudes toward HIV/AIDS although the findings was not significant.

Meanwhile, the results of previous study by Tavoosiand colleagues (2004) demonstrated that males and females students were probably same unfavorably attitudes toward HIV/AIDS disease, with males $(50 \%)$ vs. females $(48 \%)$ were agreed that HIV/AIDS-infected students should not allowed to attend an ordinary schools; males (37\%) vs. females $(36 \%)$ prefer not to sit in a class near a person with HIV positive; and males (24\%) vs. females (24\%) expressed they would not shake hands with a HIV positive person.

\section{METHOD}

The purpose of this chapter is to discuss the research methodology which would be used in this current study. Discussions are divided into seven subtopics, which include research designs, location of the study, sampling, instrumentations and measurements, pilot study (reliability), data collection, and data analysis. The purpose of research design is to identify the most economical method in conducting the research. The nonexperimental quantitative research design which is in questionnaire tools has used to finalize results that are based on hypothesis testing to achieve the objectives for this current study. Besides, three techniques of research design are descriptive, correlation and comparative also have been chosen in this study. Descriptive design is used to gather the quantitative information and then organizes, tabulates, depicts, and describes the data collection. Descriptive involved in this study will be given a general description about respondent's personal characteristic (gender), level of knowledge in
HIV/AIDS and attitudes toward HIV/AIDS.

The correlation design is applied to determine the linear relationship between personal characteristic (gender), knowledge and attitudes towards HIV/AIDS among FEM undergraduates. The result of the correlation can be positive and negative. If the result is positive correlation, then the changes in value of one variable will make the changes of the other variables in the same direction, or vice versa.Comparative design is used to survey the knowledge and attitudes toward HIV/AIDS between male and female. The gender differences can be study by comparing the difference in level of knowledge and attitudes toward HIV/AIDS.

The location of this present study conducted at FEM in UPM, Serdang, SelangorDarulEhsan, Malaysia. One of the reasons for the FEM students were choose to access in this study as they are expected to be expert in the related fields of social science, humanities and development such as anthropology, psychology, social work, community development and urban and rural studies. This is good idea for me to investigate whether the students had a good knowledge and positive attitudes toward HIV/AIDS or not since their field of study is more associated to the humanities.

The population of this study is targeted to the undergraduates from Human Ecology in UPM, Serdang. The sample size for the study is determined by the calculation formula (Israel, 2009). The minimum sample size for FEM is approximately 271 , which is calculated by the formula of known population size $(\mathrm{N}=835)$ with the $95 \%$ confidence level and confidence interval of $5 \%$. Sample size of FEM is 326 after an extra $20 \%$ is included for the purpose of accuracy and in projection of any incomplete 
filled or missing data. However, there is only 275 online answered questionnaire will be randomly selected and used it in actual sample size of the research study.

Besides, the respondents in this current study were surveyed using a method of simple random sampling design with probability proportionate to size. This sampling technique is used in this study due to the problem of gender imbalance where females now in a substantial majority as students in most university faculties, including FEM in UPM, Serdang. Therefore, male and female students have been selected with the ratio $4: 6$ where 110 of males and 165 of females from the sample size of 275 as shown in the Figure 2.

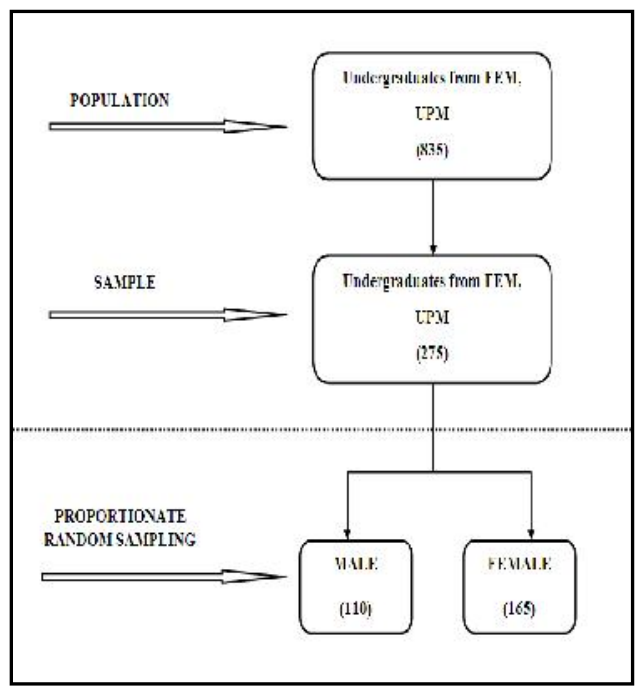

Figure 2: Proportionate random sampling method

\section{Instrumentationsand Measurement}

This current study involved two variables which are knowledge of HIV/AIDS and attitudes toward HIV/AIDS. Both variables were measured by HIV/AIDS Knowledge and Attitudes Scale for Hispanics. The instrument was developed by Luquis and Koch (1991).

The knowledge of HIV/AIDS was measured by the HIV/AIDS Knowledge scale. The scale is internal consistent as it has reliability of Cronbach's alpha of 0.61 . There are two parts of HIV/AIDS knowledge are measured by the scale. The first part is General Knowledge, which contains 21 items about the prevalence, risk factors, course of the disease, diagnosis, and prevention of HIV/AIDS. The second part is Likelihood of Transmission, concentrates on the modes of HIV transmission and contains 16 items about possible ways to transmit HIV. The highest possible score for these two parts in HIV/AIDS Knowledge scale is 44 .

For the General Knowledge part of the HIV/AIDS knowledge scale, respondents need to answer the 21 items as either (1) definitely true, (2) probably true, (3) probably false, (4) definitely false, or (5) don't know. While responses to the items of Likelihood of Transmission, concentrates on the modes of HIV transmission and contains 16 items about possible ways to transmit HIV are (1) very likely, (2) somewhat likely, (3) somewhat unlikely, (4) very unlikely, (5) definitely not possible, or (6) don't know. The overall knowledgescore is computed based on simple sum scores, means one point is given for every correct answer. Higher scores indicate greater HIVrelated knowledge or vice-versa.

One point is given for every correct answers in the first part of the HIV/AIDS Knowledge scale, with the highest possible score is 21 : (1)definitelytrue for items 1, 3, 5, 8, 10, $11,12,14,15,18,19,20,21$; (1) definitely true or (2) probably true for items 7; and (4) definitely false for items $2,4,6,9,13,16,17$. While one point is given for the correct answers in second part of the HIV/AIDS Knowledge scale, with the highest possible score is 23: (1) very likely for items 28, 35, 36; (4) very unlikely for items 24, 29; and (5)definitely not 
possible for items 22-23, 25-27, and 30-34. For item 37 , one point each is given for ticking $b, c, f, h$ and not ticking $\mathrm{a}, \mathrm{d}, \mathrm{e}, \mathrm{g}$.

The list of Knowledge of HIV/AIDS questionnaire had shown as below:
Part 1: This Part is to measure general knowledge level which contains 21 items about the prevalence, risk factors, course of the disease, diagnosis, and prevention of HIV/AIDS

\begin{tabular}{|l|l|}
\hline No. & \multicolumn{1}{|c|}{ Statement } \\
\hline 1. & AIDS can reduce the body's natural protection against diseases. \\
\hline 2. & AIDS is especially common in older people. \\
\hline 3. & AIDS can damage the brain. \\
\hline 4. & AIDS usually leads to heart disease. \\
\hline 5. & AIDS result from an infectious disease caused by a virus. \\
\hline 6. & College students are not at risk of contracting AIDS. \\
\hline 7. & AIDS leads to death. \\
\hline 8. & A person can be infected with HIV and not have the disease AIDS. \\
\hline 9. & Looking at a person is enough to tell if he or she has HIV. \\
\hline 10. & $\begin{array}{l}\text { Any person with AIDS can pass it on to someone else during unprotected } \\
\text { sexual intercourse. }\end{array}$ \\
\hline 11. & A person who has HIV can look and feel healthy and well. \\
\hline 12. & A pregnant woman who has HIV can give the virus to her baby. \\
\hline 13. & $\begin{array}{l}\text { There is a vaccine available to the public that protects a person from getting } \\
\text { HIV. }\end{array}$ \\
\hline 14. & There is no cure for AIDS at the present time. \\
\hline 15. & It may be more than 5 years before a person infected by HIV develops AIDS. \\
\hline 16. & A person can be diagnosed with AIDS by taking one special blood test. \\
\hline 17. & Using any type of condom can help protect you from AIDS. \\
\hline 18. & Younger are at greater risk of getting AIDS than the rest of the population. \\
\hline 19. & The epidemic of HIV/AIDS remained stable in Malaysia. \\
\hline 20. & Everyday, an average of 10 people tested with positive HIV in Malaysia. \\
\hline & \\
\hline
\end{tabular}

Part 2: This Part is to measure the knowledge on the possible ways to transmit HIV which contains 16 items about the likelihood of transmission and concentrates
on the modes of HIV transmission.

\begin{tabular}{|l|l|}
\hline No. & \multicolumn{1}{|c|}{ Statement } \\
\hline 21. & $\begin{array}{l}\text { There arean estimated } 100,000 \text { or more people living with HIV in } \\
\text { Malaysia. }\end{array}$ \\
\hline 22. & Living near a hospital or home for AIDS patients. \\
\hline 23. & Working near someone with HIV. \\
\hline 24. & Kissing with exchange of saliva someone who has HIV. \\
\hline 25. & Eating in a restaurant where the cook has HIV. \\
\hline 26. & $\begin{array}{l}\text { Shaking hands, touching, or kissing on the cheek someone who has } \\
\text { HIV. }\end{array}$ \\
\hline
\end{tabular}


Al-Fikra: Jurnal IImiah Keislaman, Vol. 16, No. 2, Juli - Desember, 2017 (176202)

\begin{tabular}{|c|c|}
\hline 27. & Using public toilets. \\
\hline 28. & Sharing needles for drug use with someone who has HIV. \\
\hline 29. & Receiving a blood transfusion from a hospital blood bank. \\
\hline 30. & Mosquito or other insect bites. \\
\hline 31. & Donating blood. \\
\hline 32. & Being coughed or sneezed on by someone who has HIV. \\
\hline 33. & Attending class with a student who has HIV. \\
\hline 34. & Sharing a dorm room with a student who has HIV. \\
\hline 35. & $\begin{array}{l}\text { Unprotected (without a condom) sexual intercourse with an HIV-infected } \\
\text { person. }\end{array}$ \\
\hline 36. & $\begin{array}{l}\text { Unprotected (without a condom) anal intercourse with an HIV-infected } \\
\text { person }\end{array}$ \\
\hline $\begin{array}{l}37 . \\
\text { (a) } \\
\text { (b) } \\
\text { (c) } \\
\text { (d) } \\
\text { (e) } \\
\text { (f) } \\
\text { (g) } \\
\text { (h) }\end{array}$ & $\begin{array}{ll}\text { Tick }(\sqrt{ }) \text { the fluids through which HIV has been transmitted: } \\
\text { saliva } \\
\text { semen } \\
\text { vaginal secretions } \\
\text { perspiration } \\
\text { urine } \\
\text { blood } \\
\text { tears } \\
\text { mother's milk }\end{array}$ \\
\hline
\end{tabular}

Attitudes toward HIV/AIDS

The attitudes toward HIV/AIDS are measured by the HIV/AIDS Attitudes scale. The scale is high internal consistent as it has high reliability of cronbach's alpha of 0.85 . There are 26 items of attitudes about the HIV and people who may be infected, sexual behavior and safer-sex practices, and discussions and learning about HIV/AIDS. There are 26 items in a 5point Likert scale, ranging from (1) (5) where (1) strongly agree, (2) agree,

\begin{tabular}{|l|l|}
\hline No. & \multicolumn{1}{|c|}{ Statement } \\
\hline 1. & I believe I have enough information about AIDS to protect myself. \\
\hline 2. & I believe women should not have sexual intercourse before marriage. \\
\hline 3. & $\begin{array}{l}\text { Activities that spread AIDS, such as some forms of sexual behavior, } \\
\text { should be illegal. }\end{array}$ \\
\hline 4. & $\begin{array}{l}\text { I feel uncomfortable when coming in contact with gay men because of the } \\
\text { risk that they may have for AIDS. }\end{array}$ \\
\hline 5. & $\begin{array}{l}\text { Civil rights laws should be enacted/enforced to protect people with AIDS } \\
\text { from job and housing discrimination. }\end{array}$ \\
\hline 6. & Male homosexuality is obscene and vulgar. \\
\hline 7. & I believe men should not have sexual intercourse before marriage. \\
\hline 8. & AIDS antibody blood test results should be confidential to avoid \\
\hline
\end{tabular}

(3) are uncertain, (4) disagree, and (5) strongly disagree. The highest possible score for the scale of attitudes toward HIV/AIDS is 130. A mean score is calculated for the HIV/AIDS Attitudes scale. The items are reversed scored are 1, 5, 8, 9, 10, 12-13, 15-16, 20-23, 25-26.

The list of Attitudes toward HIV/AIDS questionnaire had shown as below: 


\begin{tabular}{|l|l|}
\hline & discrimination against people with positive results. \\
\hline 9. & I feel that more time should be spent teaching students about AIDS. \\
\hline 10. & $\begin{array}{l}\text { People should not blame the homosexual community for the spread of } \\
\text { AIDS in the Malaysia. }\end{array}$ \\
\hline 11. & AIDS is a punishment for immoral behavior. \\
\hline 12. & I feel secure that I have reduced all risk of personally contracting AIDS. \\
\hline 13. & It would not bother me to attend class with a person with AIDS. \\
\hline 14. & Anyone who has had more than one sexual partner is promiscuous. \\
\hline 15. & I could comfortably discuss AIDS with a friend. \\
\hline 16. & I would not avoid a friend if he/she had AIDS. \\
\hline 17. & If I discovered that my roommate had AIDS, I would move out. \\
\hline 18. & I do not believe in using condoms. \\
\hline 19. & I could not discuss AIDS with my parents. \\
\hline 20. & I would date a person with HIV. \\
\hline 21. & I would feel comfortable discussing AIDS in a classroom situation. \\
\hline 22. & I would not engage in sexual intercourse before marriage. \\
\hline 23. & $\begin{array}{l}\text { I would feel comfortable asking a new partner about his/her sexual } \\
\text { history. }\end{array}$ \\
\hline 24. & I would use AIDS as an excuse to avoid any sexual relationships. \\
\hline 25. & I would limit myself to one sexual partner. \\
\hline 26. & I would use a condom every time I had sex. \\
\hline
\end{tabular}

\section{Pilot Study}

The purpose of this pilot study is to test the reliability and validity of the instrument and ensure that the scales were suitable to be applied in this research. This pilot study was carried out in February, 2012 and a total number of thirty undergraduates from FEM in UPM were randomly selected to answer the questionnaire through online. From the result of pilot study, it was produced a reliable Cronbach's alpha value for the HIV/AIDS Knowledge and AttitudesScales for Hispanic. The summary of the reliability result for Knowledge and Attitudes ScalesforHispanicin original study, pilot study and current study were shown in the below Table 1Table 1: Summary of the reliability cronbach alpha value

\begin{tabular}{|c|c|c|c|}
\hline \multirow{2}{*}{ Scale } & \multicolumn{3}{|c|}{ Cronbach's Alpha Value $(\alpha)$} \\
\cline { 2 - 4 } & $\begin{array}{c}\text { Original } \\
\text { Study }\end{array}$ & $\begin{array}{c}\text { Pilot } \\
\text { Study } \\
(\mathrm{n}=30)\end{array}$ & $\begin{array}{c}\text { Current } \\
\text { Study } \\
(\mathrm{n}=275)\end{array}$ \\
\hline HIV/AIDS Knowledge & 0.610 & 0.635 & 0.856 \\
\hline HIV/AIDS Attitudes & 0.850 & 0.766 & 0.766 \\
\hline
\end{tabular}

\section{Data Collection}

The online survey method by using Google Documents has been utilized in the present study to collect sufficient data in the selected faculty. Google Documents is a free, web-based spreadsheet, form and data storage services offered by Google. To create 
this online questionnaire must have a Gmail account. To conduct this online survey must also need to obtain the email addresses from those undergraduates of FEM as the respondents. After that, invitation link of online questionnaires will be sent out to the respondents. Later, all the completed response to the questions will be reply from those respondents and their answers will automatically collected and saved in an Excel spreadsheet and that makes it easier for me to input the large sets of data into the SPSS to analyse the desired resultTable 2: Section division for the questionnaire

\begin{tabular}{|l|l|}
\hline Part A & $\begin{array}{l}\text { Respondent's Personal } \\
\text { Characteristic }\end{array}$ \\
\hline Part B & Knowledge of HIV/AIDS \\
\hline Part C & Attitudes toward HIV/AIDS \\
\hline
\end{tabular}

The online questionnaire divided into three parts as shown in the above Table 2. Each respondent is required to answers all parts in the questionnaire. For the Part $A$, respondent need to indicate their gender either male or female. In Part B and Part $\mathrm{C}$, respondent required to answer questions on all items regarding the knowledge and attitudes toward HIV/AIDS. The confidentiality of the survey also was assured to protect all the respondents' privacy since Google Documents is an anonymous survey inside Google applications. The duration of this online survey has been carried out for three weeks to collect all the data and information.

\section{Data Analysis}

The data gathered will be analysed by using Statistical Package of the Social Science (SPSS). Types of statistical measures, i.e. Descriptive, Pearson correlation, T-test and Multiple regression statistics are used to analyse the findings in this study. The univariate analysis described by using the descriptive statistics while bivariate analysis used to determine the relationship between two variables in this study. Two types of bivariate analysis that used in data analysis are Pearson Correlation and T-test.

Descriptive analysis is used to identify and describe the distributional characteristics of the variables in the study. The univariate data (Specific objective (1)) is described by using the descriptive statistics to give general descriptions of the data. Descriptive statistics result would be reported using frequency $(\mathrm{N})$, percentage $(\%)$, standard deviation, mean, minimum and maximum.

The correlation between two variables reflects the degree to which the variables were related, while Pearson's correlation reflects the degree of linear relationship between variables. Pearson Correlation test is employed to analyze bivariate data (Specific objective (2)) in this study to measure linear relationship between two variables. Hence, hypothesis (Ho1) would test to indicate the significance of the variables. The Pearson correlation coefficient $(r)$ is a measure of the strength of the relationship between two variables, which ranges from +1 to -1 . Whereas, T-test used for hypothesis (Ho2, Ho3) was to compare the means of two independent groups such as gender (male and female) is statistically different from each other.

Meanwhile, the Multiple Regression analysis is applied to test on the multivariate data (Specific objective (5)). The significant predictors were combined and the result from this analysis is used to determine factors that can uniquely predict dependent variables. The multiple regression analysis is employed to test 
Hanina Halimatussaidiyah Hamsan, Lee Mei Siah; Islamic Khowledge and

Attitudes Toward HIVIAIDS among undergraduates in UPM Serdang

hypothesis (Ho4), which is determine the unique predictor of attitudes toward HIV/AIDSamong undergraduates in UPM.

\section{Research Findings And Discussion}

This chapter presents and discusses the findings based on the research objectives and hypotheses. This research aims to examine the relationships between knowledge and attitudes toward HIV/AIDS among undergraduates of Human Ecology in UPM. In summarize, all the results from the analyses are based on significance level of $p \leq 0.05, p \leq 0.01$ and $p \leq$ 0.001 , will be discussed according to the following subtopics.

Personal Characteristic (gender), Level of Knowledge on HIV/AIDS and Attitudes toward HIV/AIDS

\section{Respondents'Personal \\ Characteristic}

The descriptive analysis of student's personal characteristic according to gender was presented in Table 3.A total of 275 respondents had participated in this study where 110 $(40 \%)$ were males and 165 $(60 \%)$ werefemales from the FacultyofHuman Ecology.

Table 3: Respondents' personal characteristic

\begin{tabular}{|l|c|c|}
\hline Variable & $\mathbf{n}$ & $\%$ \\
\hline Gender & & \\
\hline Male & 110 & 40 \\
\hline Female & 165 & 60 \\
\hline
\end{tabular}

Level of HIV/AIDS Knowledge

Respondents' level of HIV/AIDS

Knowledge was measured by obtaining the undergraduates' total score in HIV/AIDS Knowledge scale (Luquis\& Koch, 1991). The total score was computed based on simple sum score where one point is given for every correct answer. The highest possible score for the HIV/AIDS Knowledge scale was 44 and the score range was within 0 to 44 . For the present study, the knowledge score of HIV/AIDS for the respondents was divided into two categories which were low (25 and below) and high (26 and above). The higher score indicated higher level of knowledge in HIV/AIDS or vice-versa.

Based on the findings in the Table 4, majority of the undergraduates $\quad(n=197, \quad 71.64 \%)$ obtained the low score whereas a few of undergraduates $(\mathrm{n}=78, \quad 28.36 \%)$ achievedhigh score of knowledge in HIV/AIDS. The minimum score was 49 whereas the maximum score was 123. The mean score was 21.97 and a standard deviation of 7.151. Thus, the result revealed that the level of knowledge on HIV/AIDS for most undergraduates of Human Ecology in UPM was low since less than one third of the respondents $(n=78,28.36 \%)$ had the higher score in HIV/AIDS knowledge.

In this study, the possibly reasons for the low level of knowledge among undergraduates of Human Ecology in UPM might be due to the lack exposure of knowledge such as a few of programs and curriculum regarding of HIV/AIDS education are organized in UPM, which also could directly contribute to their low knowledge about HIV/AIDSsince they did not have a good knowledge and clear understanding on the HIV/AIDS aspect.This idea can be supported by Pramanik, KoopmanandChartier (2006) which demonstrated that the greater exposure to the HIV/AIDS education tends to be more knowledgeable in HIV/AIDS.

Table 4: Level of HIV/AIDS knowledge 
Al-Fikra: Jurnal IImiah Keislaman, Vol. 16, No. 2, Juli - Desember, 2017 (176202)

\begin{tabular}{|l|l|c|}
\hline Variable & $\mathrm{n}$ & $\%$ \\
\hline $\begin{array}{l}\text { Level of HIV/AIDS } \\
\text { Knowledge }\end{array}$ & 275 & 100 \\
\hline Low (25 and below) & 197 & 71.64 \\
\hline High (26 and above) & 78 & 28.36 \\
\hline & & \\
\hline Mean & 21.97 & \\
\hline Sd. & 7.151 & \\
\hline Min. & 7 & \\
\hline Max. & 42 & \\
\hline
\end{tabular}

Note. Sd. = Standard deviation, Min. = Minimum, Max. = Maximum

\section{Attitudes toward HIV/AIDS}

Respondents' attitudes toward HIV/AIDS was assessed by the instrument created by Luquis and Koch in year 1991 which consisted of 26 items. Response ranged by likert scale from (1) strongly agree to (5) strongly disagree. The highest possible score for the scale of attitudes toward HIV/AIDS was 130 and the score range was within 26 to 130. The attitudes toward HIV/AIDS score for the respondents was divided into 2 categories which were low (86 and below) and high (87 and above). The higher score indicated more positive attitudes toward HIV/AIDS or vice-versa.

From the result in the Table 5, more than half of the respondents $(n=178,64.73 \%)$ had low score in 86 and below whereas only few of respondents $(n=97,35.27 \%)$ gained the high score range in 100 and above. The minimum and maximum score of the respondents were 7 and 42 respectively. The reported mean was 82.25 and the standard deviation was 11.534 in this study. The findings in this present study showed that most undergraduates of Human Ecology in UPM had negative attitudes toward HIV/AIDS.
In this study, the reason to undergraduates of Human Ecology who had negative attitudes toward HIV/AIDS was due to theirlow level of knowledge or some misconception on HIV/AIDS education, which could directly contribute to their unfavourable and negative attitudes toward HIV/AIDS. This idea can be supported by the prior studies, which indicated that knowledge about HIV/AIDS was significant influence the attitudes toward HIV/AIDS (Montazeri, 2005; Meundi et al., 2008;Rahnama et al., 2011;Suominen et al., 2011).

Table 5: Attitudes toward HIV/AIDS

\begin{tabular}{|l|c|c|}
\hline Variable & $\mathrm{n}$ & $\%$ \\
\hline $\begin{array}{l}\text { Attitudes towa } \\
\text { HIV/AIDS }\end{array}$ & 275 & 100 \\
\hline $\begin{array}{l}\text { Negative(86 and } \\
\text { below) }\end{array}$ & 178 & 64.73 \\
\hline $\begin{array}{l}\text { Positive(87 and } \\
\text { above) }\end{array}$ & 97 & 35.27 \\
\hline Mean & 82.25 & \\
\hline Sd. & 11.534 & \\
\hline Min. & 49 & \\
\hline Max. & 123 & \\
\hline
\end{tabular}

Note. Sd. = Standard deviation, Min. = Minimum, Max. = Maximum

\section{Relationship between Knowledge} and Attitudes toward HIV/AIDS

The correlation of knowledge and attitudes toward HIV/AIDS was presented in Table 6. The Pearson Correlation was computed to determine the relationship between knowledge and attitudes toward HIV/AIDS. Finding reveals that there was a significant relationship between knowledge and attitudes toward HIV/AIDS with the $r=0.315$ and $p \leq$ 0.001. The positive correlation indicated that low level knowledge of HIV/AIDS generally showed more negative attitudes toward HIV/AIDS or 
Hanina Halimatussaidiyah Hamsan, Lee Mei Siah; Islamic Khowledge and

Attitudes Toward HIVIAIDS among undergraduates in UPM Serdang

vice-versa. Hence, null hypothesis was rejected.

The result in this present study was found similar in the previous literature researches studies which indicated that a correlation between knowledge and attitudes toward HIV/AIDS. These prior studies concluded that students with higher knowledge in HIV/AIDS had more positive attitudes toward HIV/AIDS (Meundi et al., 2008;Montazeri, 2005; Suominen et al., 2011; Tavoosi et al., 2004). Besides, this similar result was also consistent with the past research which indicated that misconceptions or inadequate of knowledge about HIV/AIDS was correlated to students' attitudes toward people with HIV/AIDS (Zhang et al., 2008; Ganczak et al., 2007; Sallar, 2009) since negative attitudes toward HIV/AIDS was influenced by the prevalent unfavourable attitudes toward people with HIV/AIDS.

In this current study, the undergraduates of Human Ecology had low level of knowledge and negative attitudes toward HIV/AIDS. The reasoncould be due to the lack of exposure in HIV/AIDS aspects that lead to misconception and low knowledge of HIV/AIDS (Pramanik, Koopman\&Chartier, 2006). For example, deficiencies in the curriculum and inconsistencies in the way information about the HIV/AIDS disease was deliver to the students could contribute to their low knowledge of HIV/AIDS, and this will directly lead to their negative attitudes toward HIV/AIDS. This reason can also be found from the past studies which indicated that knowledge was significantly affect attitudes toward HIV/AIDS (Montazeri, 2005; Meundi et al., 2008; Rahnama et al., 2011; Suominen et al., 2011).
Table 6: Relationship between knowledge and attitudes toward HIV/AIDS

\begin{tabular}{|c|c|c|}
\hline \multirow{2}{*}{ Variable } & \multicolumn{2}{|c|}{$\begin{array}{c}\text { Attitudes toward } \\
\text { HIV/AIDS }\end{array}$} \\
\cline { 2 - 3 } & $\begin{array}{c}\text { Correlation } \\
(\mathrm{r})\end{array}$ & $\begin{array}{c}\text { Sig.(2- } \\
\text { tailed })(p)\end{array}$ \\
\hline $\begin{array}{l}\text { HIV/AIDS } \\
\text { Knowledge }\end{array}$ & 0.315 & 0.000 \\
\hline
\end{tabular}

Note: $\mathrm{p}$ is significant at value $\leq 0.001$

\section{TheLevel of Knowledgeon HIV/AIDS between Male and Female}

The HIV/AIDS knowledge between male and female was presented in the Table 7. In the study, T-test was employed to compare the level of knowledge on HIV/AIDS across gender. Finding showed that there was a significant difference level of knowledge on HIV/AIDS between male and female with the t-value 3.958 $(p \leq 0.001)$. Thus, null hypothesis was successfully rejected. This result was similar with the past research finding which found that there was a gender difference in knowledge about HIV/AIDS (Albrektsson et al., 2009; Ganczak et al., 2007; Jose et al., 2011; Pramanik, Koopman\&Chartier, 2006; Vasan, Sarma \& Thankappan, 2000).

The two mean values for the level of HIV/AIDS Knowledge were 24.14 (male) and 20.53 (female), and this revealed that male and female undergraduates of Human Ecology in UPM had low level of knowledge on HIV/AIDS. However, these two different mean values distinguish that male had higher level of HIV/AIDS knowledge than female. This result was supported by the prior researches which suggested that male had higher knowledge level in HIV/AIDS as compared to the female (Ganczak et al., 2007; Jose et al., 2011; Pramanik, 
Koopman\&Chartier, 2006; Vasan, Sarma\&Thankappan, 2000).

Based on the past literature studies, the reason for male undergraduates had better knowledge than their female counterparts in this current study because ofthatthe males had greater exposure of education on HIV/AIDS

(Pramanik, Koopman\&Chartier, 2006), and might be also that the males were more comfortable to talk and learn about HIV/AIDS more than females who may be feel shy or not comfortable to talk about such sensitive issue (Jose et al., 2011).

Table 7: HIV/AIDS knowledge between male and female

\begin{tabular}{|c|c|c|c|c|}
\hline \multirow[t]{2}{*}{ Variable } & \multicolumn{2}{|c|}{ Mean } & \multirow{2}{*}{$t$} & \multirow{2}{*}{$\begin{array}{l}\text { Sig.(2- } \\
\text { Tailed) } \\
\text { (p) }\end{array}$} \\
\hline & Male & $\begin{array}{l}\mathrm{Fe}- \\
\text { male }\end{array}$ & & \\
\hline $\begin{array}{l}\text { HIV/AIDS } \\
\text { Knowledge }\end{array}$ & 24.14 & 20.53 & 3.958 & 0.000 \\
\hline
\end{tabular}

Note.p is significant at value $\leq 0.001$

\section{The Attitudes toward HIV/AIDS between Male and Female}

From the Table 8, T-test was applied to compare the attitudes toward HIV/AIDS between male and female. The findings reported that there was a significant difference of attitudes toward HIV/AIDS across gender with the t-value $3.334(\mathrm{p} \leq$ 0.001 ). Therefore, null hypothesis was successfully rejected. This current finding was consistent with the prior research studies which indicated that there was a significant gender difference with attitudes toward HIV/AIDS diseases (Baron \& Byrne, 2002; Ganczak et al., 2007; Tan et al. 2007; Tavoosi et al., 2004).

The reported mean values of attitudes toward HIV/AIDS were 85.04 (male) and 80.39 (female), and this revealed that both male and female had negative attitudes toward HIV/AIDS. However, these two different mean values showed that male had better attitudes toward HIV/AIDS as compared to female. This result was in contrast with the results of earlier research studies where found that females were more tolerant and positive attitudes toward HIV/AIDS (Baron \& Byrne, 2002; Ganczak et al., 2007; Tavoosi et al., 2004).

However, it was consistent with the finding of Tan and colleagues (2007) which mentioned that male showed more acceptance and positive attitudes than their female couterparts. The reason of that the male showed more favourable attitudes could be due to the male had high level of knowledge about HIV/AIDS than female, which directly lead their positive attitudes toward HIV/AIDS. This reason can be supported by the past findings which found that there was a significant correlated between knowledge and attitudes toward HIV/AIDS (Montazeri, 2005; Meundi et al., 2008;Rahnama et al., 2011; Suominen et al., 2011).

Table 8: Attitudes toward HIV/AIDS between male and female

\begin{tabular}{|l|c|l|c|c|}
\hline \multirow{2}{*}{ Variable } & \multicolumn{2}{|c|}{ Mean } & \multirow{2}{*}{$t$} & $\begin{array}{c}\text { Sig.(2- } \\
\text { Tailed) } \\
(p)\end{array}$ \\
\cline { 2 - 5 } & Male & $\begin{array}{l}\text { Fe- } \\
\text { male }\end{array}$ & & \\
\hline $\begin{array}{l}\text { Attitudes } \\
\text { toward } \\
\text { HIV/AIDS }\end{array}$ & 85.04 & 80.39 & 3.334 & 0.001 \\
\hline
\end{tabular}

Note.p is significant at value $\leq 0.001$

\section{The Unique Predictor of Attitudes toward HIV/AIDS}

Multivariate regression was used to study the association of multiple variables with select the unique 
Hanina Halimatussaidiyah Hamsan, Lee Mei Siah; Islamic Khowledge and Attitudes Toward HIVIAIDS among undergraduates in UPM Serdang

predictors of the scores for attitudes toward HIV/AIDS. From the the analysis in Table 9 showed thatboth variables where gender and level of HIV/AIDS Knowledge to predict the attitudes scores toward HIV/AIDS were statistically significant ( $\mathrm{p} \leq$ 0.001). Hence, null hypothesis was successfully rejected. The adjusted $R$ square value was 0.114 and this indicated that students' gender and knowledge contribute only $11.4 \%$ of variance in attitudes toward HIV/AIDS. However,thelevel of HIV/AIDS Knowledgeemerged the most unique predictor of the overall attitudesscoresamong undergraduates of the Human Ecology, UPM(F = 17.559, $p \leq 0.001$ and $\beta=0.283$ ).

Table 9: Unique predictor of attitudes toward HIV/AIDS

\begin{tabular}{|l|l|l|}
\hline Variable & $\beta$ & $p$ \\
\hline
\end{tabular}

Table 10: Summary of findings on hypotheses testing

\begin{tabular}{|c|c|c|}
\hline Sepecific Objectives & Hypothesis & 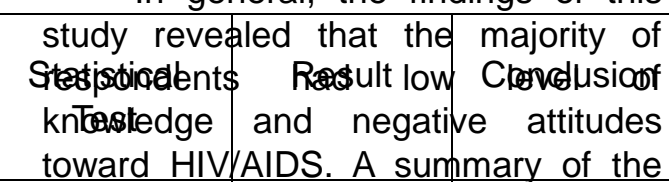 \\
\hline $\begin{array}{l}\text { To describe personal } \\
\text { characteristic (gender), } \\
\text { level of knowledge on } \\
\text { HIV/AIDS, and attitudes } \\
\text { toward HIV/AIDS. }\end{array}$ & - & $\begin{array}{l}\text { Desseintidke findings in this study can be } \\
\text { explained according to the research } \\
\text { objectives and its hypotheses. First, } \\
\text { findings presented that the level of } \\
\text { knowledge in HIV/AIDS was significant }\end{array}$ \\
\hline $\begin{array}{l}\text { To } \\
\text { therelationship between } \\
\text { knowledge and attitudes } \\
\text { toward HIV/AIDS. }\end{array}$ & Ho1 & 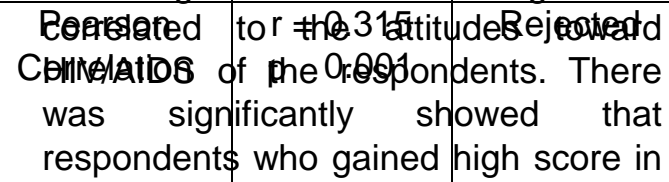 \\
\hline $\begin{array}{l}\text { To compare the } \\
\text { knowledge } \\
\text { ofHIV/AIDSbetweenmale } \\
\text { and female. }\end{array}$ & $\mathrm{Ho} 2$ & 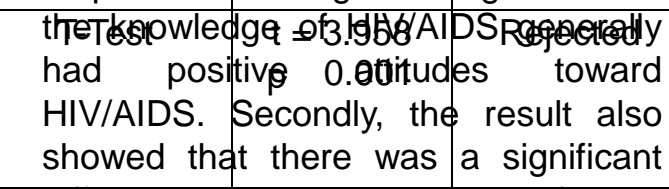 \\
\hline $\begin{array}{l}\text { To compare the attitudes } \\
\text { towardHIV/AIDSbetween } \\
\text { male and female. }\end{array}$ & Ho3 & 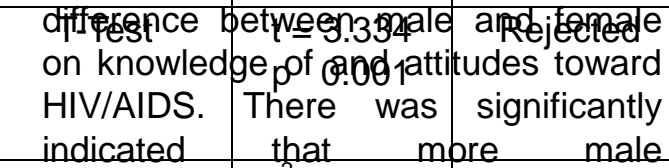 \\
\hline $\begin{array}{l}\text { To determine what factors } \\
\text { uniquely predict attitudes } \\
\text { toward HIV/AIDS. }\end{array}$ & Ho4 & 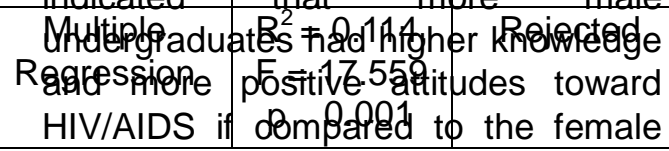 \\
\hline
\end{tabular}

\begin{tabular}{|c|c|c|}
\hline $\begin{array}{l}\text { Student's } \\
\text { gender }\end{array}$ & -0.128 & 0.031 \\
\hline $\begin{array}{l}\text { HIV/AIDS } \\
\text { Knowledge }\end{array}$ & 0.283 & 0.000 \\
\hline Constant & 74.015 & 0.000 \\
\hline$\frac{\text { on }}{\mathrm{R}^{2}}$ & 0.114 & \\
\hline $\mathrm{F}$ & 17.559 & \\
\hline$p$ & 0.000 & \\
\hline
\end{tabular}

Note.p is significant at value $\leq 0.001$

\section{Summary of the Findings}

Table 10 in the below showed the summary of the result of research objectives based on hypotheses testing in the current study. A total of 7 hypotheses were tested in this study and all hypotheses were successfully rejected. 
undergraduates. Lastly, the analyses also reported that the level of knowledge in HIV/AIDS was the most unique predictor as compared to the factor of personal characteristic (gender) that contributed to the attitudes toward HIV/AIDS among undergraduates of Human Ecology in UPM, Serdang. Therefore, this study in overall concluded that knowledge of HIV/AIDS play an important role to influence undergraduates' attitudes toward HIV/AIDS.

In conclusion, this research of study has reached the research objectives that have been addressed as below:Objective 1: To describe personal characteristic (gender), level of knowledge on HIV/AIDS and attitudes toward HIV/AIDS The first objective in this study was to identify the respondents' gender, knowledge and attitudes toward HIV/AIDS. The total sample of this study consists of $110(40 \%)$ males and 165 (60\%) females from Faculty of Human Ecology in UPM, Serdang. Meanwhile, the HIV/AIDS Knowledge and Attitudes Scales for Hispanic were used to access respondents' knowledge and attitudes toward HIV/AIDS. Result of the item analyses concluded that majority of theundergraduates (71.64\%) had low level of HIV/AIDS knowledge (25 and belowscore, $\mathrm{M}=$ $21.97, \mathrm{SD}=7.151$ ) and they also showed negative attitudes towardHIV/AIDS $(\mathrm{M}=82.25, \mathrm{SD}=$ 11.534). The students' knowledge and attitudes toward HIV/AIDS in this current resultwas consistent with the findings in the previous studies which indicated knowledge about HIV/AIDS was significant influence the attitudes toward HIV/AIDS (Montazeri, 2005; Meundi et al., 2008;Rahnama et al., 2011; Suominen et al., 2011). This means that low understanding of knowledge on HIV/AIDS education can directly contribute to their negative attitudes toward HIV/AIDS.
The result showed that there was a significant relationship between knowledge and attitudes toward HIV/AIDSof the respondents ( $p \leq$ $0.001)$. The positive correlation $(r=$ 0.315) indicated that the undergraduates who had higher level of HIV/AIDS knowledge generally had more positive attitudes toward HIV/AIDS. Therefore, this finding was generally supported by the idea of several prior researchers which they have found that those students with high level of knowledge on HIV/AIDS had more favourable attitudes toward HIV/AIDS (Meundi et al., 2008;Montazeri, 2005; Suominen et al., 2011; Tavoosi et al., 2004).

Objective 3: To compare the knowledge of HIV/AIDS between male and femaleThe result of Objective 3 was computed by using T-test, found that there was a significant difference level in knowledge of HIV/AIDS between male and female undergraduates of Human Ecology, UPM $(t=3.958, p \leq 0.001)$ where the male undergraduates $(M=24.14)$ had higher level of knowledge about HIV/AIDS than the female undergraduates $(\mathrm{M}=20.53)$. This result was consistent with several past studies which reported a high knowledge on HIV/AIDS among male than their female counterparts (Ganczak et al., 2007; Jose et al., 2011; Pramanik, Koopman\&Chartier, 2006; Vasan, Sarma\&Thankappan, 2000).

Objective 4: To compare the attitudes toward HIV/AIDS between male and female .The finding of Objective 4 was also computed by using T-test, showed that there was a significant difference in attitudes towardHIV/AIDS across gender among undergraduates of Human Ecology, UPM $(\mathrm{t}=3.334, \mathrm{p} \leq 0.01)$ where the male had more positive attitude toward HIV/AIDS ( $\mathrm{M}=85.04$ ) compared to theirfemale counterparts $(\mathrm{M}=$ 
80.39).This current finding was general similar with the previous research result which indicated that male showed more acceptance and positive attitudes as compared to the female (Tan et al., 2007). However, it was inconsistent with the findings of earlier research studies where found that females were more tolerant and positive attitudes toward HIV/AIDS (Baron \& Byrne, 2002; Ganczak et al., 2007; Tavoosi et al., 2004) Objective 5:To determine what factors uniquely predict attitudes toward HIV/AIDSThe result of Objective 5 was analyzed by using a multiple regression revealed that the regression coefficient was significant $\left(R^{2}=0.114, F=17.559, p \leq\right.$ 0.001 ) where the level of HIV/AIDS knowledgeindicated the most unique predictor in predicting the attitudes toward HIV/AIDS among undergraduates of Human Ecology, UPM. $(\beta=0.283, p \leq 0.001)$.

\section{Implications}

This current research study offers some important contributions. In short, the findings showed that the knowledge as more significant predictors of attitudes toward HIV/AIDS and there also was a significant relationship between the knowledge and attitudes toward HIV/AIDS. Hence, this showed that knowledge play an important role to influence the attitudes among undergraduates of Human Ecology.As evidenced by the present results, the higher level of knowledge about HIV/AIDS could lead to more favourable attitudes toward HIV/AIDS and this finding was consistent with past studies (Montazeri, 2005; Meundiet al., 2008;Rahnama et al., 2011; Suominen et al., 2011). Thus, it is quite important to have a deeper understanding on HIV/AIDS education among undergraduates of Human Ecology since they will possibly recognized as an important role to take the responsibility of social welfare in their future work. Therefore, this precise information can be useful for UPM to implement the relevant program, intervention and prevention strategies in aiding them to enhance their awareness about the right perception on HIV/AIDS and this can contribute them to develop more humanistic and positive attitudes toward HIV/AIDS.

Additionally, the result of the study also revealed that undergraduates of Human Ecology had a low level of knowledge and attitudes toward HIV/AIDS. From the findings, male performed better in knowledge and showed more positive attitudes than their female counterparts. These findings imply that there is need to address, especially emphasizes on the female undergraduates' misconceptions about the HIV/AIDS and attitudes toward the disease. As stated by Chen et al. (2007), the increase in accurate knowledge and improve understanding of HIV/AIDS are important to reduce the negative attitudes. Thus, this is a good time to promote more HIV/AIDS education program to disseminate facts about HIV/AIDS among relevant university students especially female students of Human Ecology in UPM, in order to raise their knowledge level such as a clearer understanding of how HIV/AIDS canbe transmitted and this most likely to bring about a highly positive attitudes towardHIV/AIDS.

\section{Recommendations}

From the findings of this study, several recommendations are made for future research. First, the current study only examined the knowledge and attitudes toward HIV/AIDS among undergraduates in UPM, Selangor because of the constraint of time and cost. Hence, future researchers are suggested to implement higher representativeness sampling method 
Al-Fikra: Jurnal IImiah Keislaman, Vol. 16, No. 2, Juli - Desember, 2017 (176202)

and also increase the sample size such as included the other universities in Malaysia. This can get more comprehensive information or data so that can generalize to wider population.Secondly, the target samples of this study only focus on university undergraduates. It is suggested that future studies to conduct a research that included the people from different age range and broader personal background so that the characteristics of whole transitional stage of human development that occur between childhood to adulthood which could explore the difference in knowledge level and attitudes toward HIV/AIDS among Malaysians. This can help our country to find the best and effective strategic to increase the awareness of HIV/AIDS among Malaysian citizen of different transitional stage.Lastly, there are many other factors (antecedent characteristics) that can influence the knowledge and attitudes toward HIV/AIDS which have been investigated by past literature studies. Other factors such as faculty (Maimaitiet al., 2010; Tan et al., 2007), age (Visser, Makin\&Lehobye, 2006; Zhang et al., 2008), race and ethnicity (Varas-Díaz, Serrano-García\& ToroAlfonso, 2005), culture (Abiona, 2006; Ellepola et al., 2011), religion (Vasan, Sarma\&Thankappan, 2000), and experience of personal interaction with HIV/AIDS infected people (Visser, Makin\&Lehobye, 2006). However, this current research only considers the respondents' gender to review the knowledge and attitudes toward HIV/AIDS. Thus, it is highly recommended to increase the scope in future study so that researchers able to draw stronger conclusion and more relevant implications. A better research should be going into depth of the scope for investigating the real profile of the respondents.

\section{BIBILIOGRAPHY}

Abiona, A. (2006). Influence of primordial culture and HIV/AIDS awareness programme on stigmatization of HIV/AIDS patients in Oyo and Osun States,Nigeria: Premise for community education intervention. International Journal of African \& African American Studies, 5 (1), 1-9.

Ayranci,U.(2005). AIDS knowledge and attitudes in a Turkish population:Anepidemiologicalstu dy.BMC Public Health, 5(95).doi:10.1186/1471-2458-595

Albrektsson, M., Alm, L., Tan, X.,\&Andersson, R. (2009). HIV/AIDS awareness,

attitudes and risk behavior among university students in Wuhan, China. Open AIDS Journal, 3(3), 55-62. doi: $10.2174 / 1874613600903010$ 055

Aluede, O., Imhonde, H.O., Maliki, A. E.,\&Alutu, A. N.G. (2005). Assessing

Nigerian University students' knowledge about HIV/AIDS, Journal of Social

Science, 11(3), 207-213.

Brehm, S.S., Kassin, S.M., \& Fein, S. (2002). Social Psychology.5th edition. Boston: MacGraw Hill.

Chen, J., Choe, M. K., Chen, S., \& Zhang, S. (2007). The effects of individual-andcommunity-level knowledge, beliefs, and fear on stigmatization of people living with HIV/AIDS in China.AIDS Care, 19(5), 666-673. doi:10.1080/0954012060098857

Colbert, A. M., Kim, S. M., Sereika, S. M., \&Erlen, J. A. (2010). An Examination ofthe Relationships Among Gender, Health Status, Social Support, and HIV-Related 
Hanina Halimatussaidiyah Hamsan, Lee Mei Siah; Islamic Khowledge and

Attitudes Toward HIVIAIDS among undergraduates in UPM Serdang

Stigma.Journal of the Association of Nurses in AIDS Care, 21(4), 302-

313.doi:10.1016/j.jana.2009.11.4

Ellepola, A. N. B., Joseph, B. K., Sundaram, D. B., \& Sharma, P. N.(2011).Knowledge and attitudes towards HIV/AIDS amongst Kuwait university dental students. European Journal of Dental Education, 15 , 165-171. doi:10.1111/j.16000579.2010.006 52. $x$

Ganczak, M., Barss, P., Alfaresi, F., Almazrouei, S., Muraddad, A.,\& Al-Maskari, F.(2007). Break the silence: HIV/AIDS knowledge, attitudes, and educational needs among Arab university students in United Arab Emirates. Journal of Adolescent Health, 40, 572.e1-572.e8. doi:10.1016/j.jadohealth.2007.01 .011

Global AIDS Response Country Progress Report (2012). Disease Control Division,Ministry of HealthMalaysia. Kuala Lumpur: Malaysia. Retrieved March 12,2012,

fromhttp://www.moh.gov.my/im ages/gallery/Report/GLOBAL AIDS Endorsed DG.pdf

GlobaAIDSOverview.(2011).AIDS.govo nline.Retrieved May 14, 2011, from

http://www.aids.gov/federalresources/around-theworld/global-aids-overview/

HIV/AIDS and maternity care in Kenya: how fears of stigma and discrimination affect uptake and provision of labor and delivery services. AIDS Care, 20(8). 938-945.

HIV Research Domains: Topic A Attitudes. (n.d). Population Council online.Retrieved October 2, 2011,
http://www.popcouncil.org/Hor izons/ORToolkit/AIDSQuest/to pics/attitudes.html

Israel, G. D. (2009). Determining sample size. Retrieved November 20, 2011, fromhttp://www.edis.ifas.ufl.ed u/pd006

Jose, O., Totona, K., Begani, A., Andew, T., Tombe, B., \&Begani, R. (2011).Knowledge, attitudes and beliefs on HIV/AIDS among tertiary students in Papua New Guinea. World Journal of AIDS, 1 , 50-61.

doi:10.4236/wja.2011.12009

Koksal, S., Namal, N., Vehid, S.,\&Yurtsever, E. (2005). Knowledge and attitude towards HIV/AIDS among Turkish students.Infectious Diseases Journal of Pakistan, 14(4),118123.

Lau J. T. F.,\&Tsui, H.Y. (2005). Discriminatory attitudes towards people living with HIV/AIDS and associated factors: A population based study in the Chinese general population. Sexually Transmitted Infections, 81(2).113119.doi:10.1136/sti.2004.011767

Li, Y.,\& S, Craig. (2008). Chinese nursing students' HIV/AIDS knowledge,attitudes and practices intention.Applied Nurse Res., 21, 147-152.

Li, X. H., Wang, H. H., Williams, A., \& $\mathrm{He}, \quad$ G. P. (2009). Stigma reported by people living with HIV in South Central China. Janac-Journal of the Association of Nurses in Aids Care, 20(1). 22-30.

doi:10.1016/j.jana.2008.09.007

Mahat, G., \& Eller, L. S. (2009). HIV/AIDS and universal precautions: Knowledge and attitudes of Nepalese nursing students. Journal of Advanced 
Al-Fikra: Jurnal Ilmiah Keislaman, Vol. 16, No. 2, Juli-Desember, 2017 (176 202)

Nursing, 65(9), 1907-1915.doi: $10.1111 / \mathrm{j} .1365-$

2648.2009.05070.x

Maimaiti, N., Shamsuddin, K., Abdurahim, A.,\&Tohti, N. (2010). Knowledge, attitude and practice regarding HIV/AIDS among University Students in Xinjiang.Global Journal of Health Science, 2(2), 51-60.

McManus, A., \&Dhar, L. (2008). Study of knowledge perception and attitudes of

adolescent girls towards STI/HIV, safer sex and sex education: A cross sectional survey of urban adolescent school girls in South Delhi, India. $B M C$ Women's Health8(12).doi:10.1186/14726874-8-12

Meundi, A.D., Amma, A., Rao, A., Shetty, S.,\&Shetty, A.K. (2008). Cross-sectional populationbased study of knowledge, attitudes, and practices regarding HIV/AIDS in Dakshina Kannada District of Karnataka, India. Journal of the International Association of Physicians in AIDS Care, 7(1), 27-34. doi: $10.1177 / 1545109707302088$

Monjok, E., Smesny, A., \&Essien E. J. (2009). HIV/AIDS-related stigma and discrimination in Nigeria: Review of research studies and future directions for prevention strategies. Africa Journal of Reproductive Health.13(3).2135.

Montazeri, A. (2005). AIDS knowledge and attitudes in Iran: Result from a population-based survey in Tehran. Patient Education and Counseling,57, 199-203. doi:10.1016/j.pec.2004.05.014

Moreland, J.P. (2009).What is Knowledge. Retrieved December 3, 2011, from http://www.boundless.org/200 5/articles/a0002116.cfm\#

Movahed, M., \&Shoaa, S. (2010). On attitude towards HIV/AIDS among Iranian students (Case study: High school students in Shiraz city). Pakistan Journal of Biological Sciences,13(6), 271278.

Naing, C. M., Hakim, M., Ang, D. T. Y., Koo, R. M., Tan, C. Y., Kong, K. J., \&Siew, S. S. K. (2010). HIV/AIDS-related knowledge, attitudes and perceptions: A cross-sectional household survey.Southeast Asian J Trop Med Public Health, 41(4), 952960.

$\mathrm{Ng}$, C. J., \& Kamal, S. F. (2006).Bridging the gap between adolescent sexuality and HIV risk: the urban Malaysian perspective.Singapore Med J, 47 , 482-90.

Norman, L. R., Carr, R., \&Jime'nez, J. (2006). Sexual stigma and sympathy: Attitudes toward persons living with HIV in Jamaica.Culture, Health \&Sexuality, 8(5), 423-433.

O'Connell, T.S., \&Cuthbertson, B. (2009).Diversity. Group dynamics in recreation and leisure: creating conscious groups through an experiential approach.

Retrieved February 21, 2012, from http://books.google.com.my/b ooks?id=pBONJXoZ4fIC\&dq= personal+characteristics+defi nition \&source $=$ gbs navlinks s

Ojebuyi, B. R. (2009).Increasing people's knowledge about HIV/AIDS: An investigation into the effectiveness of reading as a communication strategy.Journal of Health Management, 11(3), 473- 
Hanina Halimatussaidiyah Hamsan, Lee Mei Siah; Islamic Khowledge and

Attitudes Toward HIVIAIDS among undergraduates in UPM Serdang

488.doi:10.1177/0972063409011

00302

Parker, R., Aggleton (2002). HIV/AIDSrelated stigma and discrimination: $\mathrm{A}$

conceptual framework and an agenda for action. Horizons Program, Tulane University. Retrieved October 2, 2011, from http://hivaidsclearinghouse.un esco.org/search/resources/hor izons.pdf

Piero, M. (2010).Learning the terms undergraduate vs. graduate. Retrieved December 3, 2011, fromhttp://www.brighthub.com/ education/college/articles/860 76.aspx

Pramanik, S., Koopman, C., \&Chartier, M. (2006).HIV/AIDS stigma \& knowledge among predominantly middle-class high school students in New Delhi, India. The Journal of Communicable Diseases, 38(1), 57-69.

Rahnama, R., Rampal, L., Lye, M.S., \&Rahman, H. A. (2011).Factors influencing students' attitude towards HIV/AIDS in a Public University, Malaysia. Global Journal of Health Science, 3(1), 128-134. doi:10.5539/gjhs.v3n1p128

Sallar, A. M. (2009). Correlates of misperceptions in HIV knowledge and attitude towards people living with HIV/AIDS (PLWHAs) among in-school and out-of-school adolescents in Ghana.Africa Health Science, 9(2), 82-91.

Sandelowski, M., Lambe, C., \&Barroso, J. (2004).Stigma in HIV positive women.Journal of Nursing Scholarship, 36(2), 122128.

Serlo, K. (2008). University students' attitudes towards HIV/AIDS in Finland and in
Kenya.ActaUniversitatisOuluensi $s$ D995. Oulu: University of Oulu.

Sowell, R. L. (2004). Access to all: Time to make a theme the reality. Journal of the Association of Nurses in AIDS Care, 15(3), 21-22.

Suominen, T., Karanja-Pernu, C., Kylma, J., Houtsonen, J., \&Va"lima"ki, M. (2011).Knowledge, attitudes and risk behaviour related to HIV and AIDS: The case of International students in a Finnish University.J Community Health.doi 10.1007/s10900-010-9353-3

Tan, X., Pan, J., Zhou, D., Wang, C., \&Xie, C. (2007). HIV/AIDS knowledge, attitudes and behaviors assessment of Chinese students: A questionnaire study. International Journal of Environmental Research and Public Health, 4(3), 248-253.

Tavoosi, A., Zaferani, A., Enzevaei, A., Tajik, P., \&Ahmadinezhad, Z. (2004).Knowledge and attitude towards HIV/AIDS among Iranian students.BMC Public Health, 4(17).

The World Health Report (WHO). (2004). Changing history. Bulletin of the World Health Organization, 82(6), 477-478.

Tung, W. C., Ding, K., \& Farmer, S. (2008). Knowledge, attitudes, and behavioursrelated to HIV and AIDS among college students in Taiwan. Journal of the

Association of Nurses in AIDS Care, 19(5), 397-408.

Turan, J. M., Miller, S., Bukusi, E. A., Sande, J.,\& Cohen, C. R. (2008). HIV/AIDS and maternity care in Kenya: how fears of stigma and discrimination affect uptake and provision of labor and delivery 
Al-Fikra: Jurnal Ilmiah Keislaman, Vol. 16, No. 2, Juli-Desember, 2017 (176 202)

services. AIDS Care, 20(8). 938945.

Turhan, O., Senol, Y., Baykul, T., Saba, R., \&Yalçin, A. N. (2010).Knowledge, attitudes and behaviour of students from a Medicine faculty, Dentistry faculty, and Medical Technology Vocational Training School toward HIV/AIDS.

International Journal of Occupational Medicine and Environmental Health,23(2), $153-160$. doi10.2478/v10001-010-0008-5

Uutela, A. (1985). Pupils' Concept about Epilepsy: What Determines Them and How They are Changed after an Educaional Program. Research Reports of Social Psychology 2.University of Helsinki, Yliopistopaino, Helsinki.UNAIDS World AIDS Day Report(2011).Joint United Nations Programme on HIV/AIDS (UNAIDS). United Nations.

Upreti, D., Regmi, P., Pant, P., \&Simkhada, P. (2009). Young people's knowledge, attitude, and behaviour on STI/HIV/AIDS in the context of Nepal: A systematic review.Kathmandu University Medical Journal, 7(4), 383-391.

Vasan, S. S. LAL.R.S., Sarma, P. S., \&Thankappan, K. R. (2000). Knowledge and

attitude of college students in Kerala towards HIV/AIDS, sexually transmitted diseases and sexuality. The National Medical Journal of India,13 , 231-236.

Varas-Díaz, N., Serrano-García, I. \& Toro-Alfonso, J. (2005). AIDSrelated stigma and social interaction: Puerto Ricans living with HIV/AIDS. Qualitative Health Research, 15 (2), 169-
187.

doi:

10.1177/1049732304272059

Visser, M. J., Makin, J. D., Lehobye, K. (2006).Stigmatizing attitudes of the community towards people living with HIV/AIDS.Journal of Community \&Applied Social Psychology, 16 ,42-58. doi: 10.1002/casp.836

Zhang, L., Li, X., Mao, R., Stanton, B., Zhao, Q., Wang, B., \&Mathur, A. (2008).Stigmatizing attitudes towards people living with HIV/AIDS among college students in China: Implications for HIV/AIDS education and prevention. Health

Education, 108(2), 130-144. doi:10.1108/0965428081085558 6 